\title{
Patterns of Precarious Employment in a Female-Dominated Sector in Five Welfare States_-The Case of Paid Domestic Labor Sector
}

\section{Merita Jokela* ${ }^{1,2}$}

This is the first quantitative comparative study that examines the relationship between paid domestic labor and precarious employment on the microlevel. Using the Luxembourg Income Study 2013/2014, it shows that across welfare regimes, domestic workers have a higher probability of working in precarious employment settings compared to other industries. Furthermore, the overlaps of two or more precarious employment settings are significantly more common in domestic work than among other industries in all countries examined. This is an important finding as it proves the high insecurity of the formal domestic labor industry even in countries with specific regulations regarding domestic work.

\section{Introduction}

"Precarious employment," contractual or temporary work that is typically poorly paid, insecure, and unprotected, has received growing attention among social scientists. Nonstandard and contingent employment relations, such as part-time and temporary jobs, are viewed as a wider structural development of labor markets in which employees bear the risks of insecurity and uncertainty (Eichhorst and Marx 2015; Kalleberg 2009; Standing 2011, 1989). Labor markets are seen as increasingly dualized, divided into "insiders" who enjoy high levels of employment protection, while "outsiders" bear the costs of the development through unemployment, or jobs characterized by low levels of protection (Rueda 2005). Dualization has been of particular concern during the present economic crisis, as outsiders tend to come from already socially and economically disadvantaged groups and certain sectors of employment (Kalleberg 2011; Rueda 2014).

\footnotetext{
${ }^{1}$ Social Policy Research Unit, National Institute for Health and Welfare, Helsinki, Finland

${ }^{2}$ Department of Social Research, University of Turku, Turku, Finland

*merita.jokela@thl.fi 
Feminist scholars particularly draw attention to the gendered consequences of precarious employment, underlining their impact on women and the female-dominated sectors of work, such as care-related occupations (Vosko 2000; Vosko, MacDonald, and Campbell 2009; Young 2010). Paid domestic work is one such occupation. At the same time, in many countries, paid domestic service is promoted as providing job opportunities for unemployed and migrant women in particular, but also relieving the "care burden" of upper- and middle-class households (European Commission 2012; Morel 2015). Previous studies on European welfare states suggest that despite the different regimes related to gender, care, employment, and migration, there is a convergence in the expansion of migrant domestic labor markets and their precarious working conditions (Hobson, Hellgren, and Bede 2015; Morel 2015; Williams 2012). In addition, numerous studies argue that due to the exceptional nature of employment in private households and the lack of collective bargaining, domestic workers are more likely to experience precarious employment conditions than other occupational groups (Anderson 2000; Lutz 2011; Tomei 2011). Others emphasize the heterogeneity of persons working in paid domestic labor, suggesting that it is the individual characteristics, such as gender, nationality, or ethnic, background that place some workers in less favorable conditions than others (Hobson and Bede 2015; Jönson and Giertz 2013; Pratt 2005).

While there is a wealth of literature on gender and precarious employment, there is a scarcity of quantitative comparative studies on the exact patterns of precarity in female-dominated sectors (see, however, Avril and Cartier 2014; Leschke 2015; Suleman 2015). In the case of paid domestic labor, previous research consists mostly of ethnographic and qualitative studies on migrant domestic workers that highlight particularly the vulnerability of undocumented migrants working in the sector (e.g. Anderson 2007, 2010; Hobson, Hellgren, and Bede 2015; Lutz 2011; Parreñas Salazar 2012). Less attention has been paid to the employment conditions of the sector in general.

Using data from the Luxembourg Income Study (LIS) of 2013/2014, this study provides insight into the interplay of paid domestic labor and precarious work in different welfare regimes: Germany, Italy, Spain, Luxembourg, and the United States. It examines the impact of industry in explaining precarious employment conditions and the role of individual characteristics in shaping precarious employment. It compares paid domestic workers' employment settings with those in another female-dominated industry-specifically, care work-and all other industries.

Earlier studies suggest that the undervaluation of care and lower status of female-dominated sectors are reflected in lower wages relative to other sectors of work (Budig and Misra 2010; England, Budig, and Folbre 2002; Lightman 2017). However, precarious employment, understood as labor market insecurity and uncertainty, is a complex phenomenon that goes beyond wages. To better understand the inequalities related to female-dominated industries and, 
particularly, low status domestic and care work, the study includes three dimensions identified in previous studies as contributing to precarity: parttime employment, job instability (job tenure and unemployment experience), and low pay work. The aim of this multidimensional approach is to examine the degree and severity of precarious employment. Part-time employment per se does not necessarily make a job "precarious," but if it overlaps with job instability or low wages, or both, the overlap may be considered as an indicator of higher risk of precarious employment.

This paper begins with a presentation of the study's comparative framework, focusing on the role of institutions in shaping the position of domestic workers. This is followed by a discussion of the relevant literature on precarious employment, paid domestic, and care work, followed by a description of the study's research design. The fourth section offers a profile of domestic workers and precarious work, followed by a multivariate analysis on the predictors of precarious employment.

\section{The Comparative Framework of the Study}

Paid domestic work has become increasingly prevalent in Western welfare states over the past two decades due to several socio-demographic developments, such as women's increasing labor force participation, population ageing, and cuts in public care provision (Lister et al. 2007). Domestic workers' position in labor markets is shaped by several macro-level factors and national context. Previous studies have highlighted the role of institutional factors and policy choices related to gender (e.g. women's employment patterns, sex segregation of jobs), care (e.g. who is responsible for the provision of care and how is care organized), migration (e.g. immigration programs and supply of migrant work force), and employment (e.g. extent of informal employment, level of regulation in the labor markets) in sustaining or mitigating inequalities in the sector and shaping the sector in general (Da Roit and Weicht 2013; Kvist 2012; Hellgren 2015; Williams and Gavanas 2008; Williams 2012).

This study focuses on Germany, Luxembourg, Italy, Spain, and the United States, which were chosen because of their fairly high prevalence of paid domestic work. At the same time, they have taken diverse approaches to regulate the sector. The five countries may be broadly grouped in three different regimes, based on their institutional settings and policies regarding paid domestic work: the Continental European, Southern European (Mediterranean), and Liberal regimes. Due to issues of data availability, it was not possible to include the fourth welfare regime, the Nordic regime, in the analysis.

The Continental European welfare states (Germany and Luxembourg) may be described as "gendered familialism," with care policies that traditionally have enforced the caring role and financial dependence of mothers (Leitner 2003). This has been ensured by financial transfers supporting families in their 
role as primary welfare providers and as a substitute for public social and care services (Morel 2007). In Germany, this is true particularly in long-term care where cash benefits are provided through the long-term care insurance for family-carers, or via families buying services from the market. In addition, a parallel system has emerged in which migrant care workers are hired by households directly, and mostly informally. These informal employment relationships naturally exclude employees from social security contributions or any formal benefits (Lutz 2009; Theobald 2010). Germany and Luxembourg are also usually presented as corporatist or conservative employment regimes with strong employment protection and transfer-oriented labor market policies (Bukodi and Róbert 2007; Esping-Andersen 1990). In Luxembourg, the prevalence of permanent job contracts is high, and temporary work is heavily restricted (OECD 2015a). Germany is characterized as a dualist labor market, where "insiders" hold regular jobs and enjoy the benefits of a high level of employment protection, while "outsiders" are left with job insecurity and weak labor protection. Both states strongly encourage the employment of domestic workers, but through different means. Similar to its neighboring countries France, Belgium, and the Netherlands, in Luxembourg, the employment of domestic staff is regulated by offering tax rebates for households up to 3600 euros per year for households that register as employers and pay social contributions for the employees. ${ }^{1}$ In Germany, a large proportion of paid domestic labor is regulated through employment policies: in 2015, around 300,000 domestic and care workers were employed by households through the Mini Job employment program that allows employees to earn 450 euros per month without paying taxes — and without the employer's responsibility to pay social contributions for the employee (Minijobzentrale 2015). The Mini Job system has been widely criticized for increased levels of precarious employment in Germany, particularly for sustaining low pay jobs such as domestic work (Prosser 2016; Simonazzi 2012; Shire 2015).

Until recently, The Southern European welfare states Spain and Italy relied primarily on the family to support those in need of care, making informal networks crucial for families (Bettio, Simonazzi, and Villa 2006; León 2010). Public care provision is still comparatively limited and informal care has partly been replaced by private care services. In elderly care, these comprise a mix of nonprofit and for-profit providers, and migrant care workers employed directly by households (Simonazzi 2008). The migrant-in-thefamily model (Bettio, Simonazzi, and Villa 2006) has received strong support from the government and other stakeholders particularly in care for the elderly where it is partly financed through tax rebates and vouchers (Kvist 2012; van Hooren 2011). Similarly to Germany, labor markets in Italy and Spain are characterized by entrenched "insider-outsider" divides but also (especially in Spain) by high levels of temporary work (Prosser 2016). In both countries, the informal economy is large and consists particularly of industries with a high share of (undocumented) migrant workforce, such as paid domestic labor 
(Bettio, Simonazzi, and Villa 2006; Shutes and Chiatti 2012). In order to reduce undocumented migration and informal work, Spain and Italy have applied ex post facto regularization of undocumented workers that has particularly targeted domestic workers (Finotelli and Arango 2011). For instance in Italy, in 2009 asylum was granted to 200,000 paperless migrants working in the domestic and care sector. Nevertheless, the regularization campaigns have only covered some of the workers and many workers remain undocumented and informal (Bettio, Simonazzi, and Villa 2006; Shutes and Chiatti 2012). In addition, a significant number of migrant domestic and care workers come from Eastern European countries to work as "circular carers," that is, only work on a temporary basis in the host country (Marchetti 2013; Triandafyllidou and Marchetti 2013).

The United States is the paradigm exemplar of the Liberal market regime with weak labor market regulation. Care is seen as a commodity bought through the markets and public support for families in need of care services is low, which fuels the demand for private care services (Parreñas Salazar 2000; Ungerson 1997). In this type of welfare regime where care provision is encouraged through unregulated markets, wages in the care sector are usually low (Morgan 2005). Moreover, paid domestic work is typically undeclared and performed by migrants, often undocumented (Michel and Peng 2012). Thus, unlike in the four other countries where paid domestic labor is (to varying degrees) regulated by specific policies, the United States has chosen a "no policy" or a "policy of demand and denial" approach in which the lack of public policies leads to high demand for private domestic and care services, while entry into formal labor markets is denied by onerous regulations (Jokela 2017; Michel and Peng 2012).

\section{Precarious Work}

Generally, "precarious work" is defined as employment under conditions that create uncertainty and insecurity for individuals in the labor market (Anderson 2010; Kalleberg 2012; Vosko 2000). Precarious jobs are typically described as jobs that lack security in at least one dimension, including no employee control over the duration of jobs, poor income and advancement prospects, and insufficient labor law coverage, collective bargaining arrangements, and welfare state benefits (Rodgers and Rodgers, 1989; Standing, 2011). In this study, part-time job instability (short job tenure and unemployment experience), and low-wage work are seen as capturing the uncertainty, instability, and low employment intensity on one hand, and the quality and wage level of the job, on the other.

Naturally, nonstandard employment relationships may not always lead to precarity, but for some, the risk is higher than for others. As Kalleberg (2011) notes, "[w]hile all jobs have become more precarious, some ... have been less 
vulnerable than others, and the labor force has become increasingly polarized into those with more education and marketable skills and those without the human capital attributes" (Kalleberg 2011). This study draws partially on Vosko's concept of precarious employment by examining, from a comparative perspective, the impact of social contexts and location, such as industry, national context, and gender and migration status, on the three dimensions of precarious employment mentioned above. Vosko defines precarious employment as "shaped by the relationship between employment status (i.e., self-employed or paid employment), form of employment (e.g., temporary or permanent, part-time or full-time), and dimensions of labor market insecurity, as well as social context (e.g., occupation, industry, and geography) and social location (or the interaction of social relations, such as gender, and legal and political categories, such as citizenship)" (Vosko 2006, 102). On the institutional level, precarious employment is more likely to occur in cases of nonrespect of labor law and high levels of undeclared work. In addition, neoliberal policies that emphasize the liberalization of employment protection are viewed to increase the prevalence of nonstandard employment and job instability in all welfare regime types (Prosser 2016).

\section{Previous Research on Precarious Employment in Domestic and Care Work}

Precarious work is commonly linked with female-dominated industries, such as care work and care-related activities, including paid domestic work. There are several explanations for this. First, the devaluation thesis related to gender stratification system theories suggests that our culture devalues women and any activity that is largely done by women, such as including taking care of persons, but also cleaning, preparing food, and doing laundry (Cancian and Oliker 2000; England, Budig, and Folbre 2002; England and Folbre 1999). While many of these tasks may be outsourced to the state or the market, it is argued that our culture and norms related to gender and motherhood influence our attitudes toward paid care work (England, Budig, and Folbre 2002). Hence, skills needed in caring labor are associated with mothering, and considered as something natural and therefore not worth decent remuneration (Steinberg 1990).

Secondly, some studies emphasize the variety of jobs and skill-levels in the care sector, suggesting that not all caring labor is equally vulnerable. In her study on care workers' earnings in North America and East Asia, Lightman (2017) found a wage penalty existed only for low status workers (such as domestic workers, and home care aides), and a wage bonus for high status care occupations, such as doctors and teachers. As Duffy, Albelda, and Hammonds (2013) explains, "... paid care work has been divided into stratified occupational categories, and those defined as interactive have been typically 
associated with white, professional, or 'semiprofessional' women, while those defined as support (and more "menial") have been associated with women of color and immigrant women" (Duffy 2007; Glenn 1992; Roberts 1997). Similarly, a study of female service sector employment found high levels of nonstandard and low wage employment in the lower strands of service occupations (Leschke 2015). In addition, institutional factors may influence the precariousness of care workers. As Folbre (2006) suggests, labor turnover is typically high and training opportunities low in low-wage and low-cost care markets, which adds to the already low quality and low pay in care services.

Among care-related industries, domestic work is said to be a particular case for several reasons. Since paid domestic labor is performed in the private sphere, in other people's homes where working conditions are less easy to control, employers (households) are seen as more likely to disregard formal regulations than in other employment relationships (Anderson 2000; Lutz 2011). Moreover, part-time work and short-term contracts are said to be common in paid domestic labor, which usually makes it difficult to develop stable jobs and decent work opportunities (Bowman and Cole 2014; Shire 2015; Tomei 2011). Previous studies also highlight the unequal treatment of domestic workers and the differences among countries in the level of legal protection of persons working in paid domestic services (Anderson 2007; Gallotti 2009; ILO 2013). In addition, social policies related to the employment of domestic workers directly or indirectly influence the level of precarity in paid domestic labor (Hellgren 2015; Hobson, Hellgren, and Bede 2015; Jokela 2017; van Hooren 2010).

A third line of research argues that inequalities related to paid domestic and care labor require analysis that takes into account the different situations and characteristics of the persons working in the sector. Transnational feminist theories particularly emphasize that intersecting identities, including class, nationality, ethnicity, and race, are equally important when analyzing ways that inequalities are reproduced (Crenshaw 1991; Mohanty 2003). These characteristics place some workers in weaker positions than others, influencing the quality of working and living conditions of domestic workers (Anderson 2000). American research in particular highlights the role of intersectionality and the impact of the race stratification system that sustains inequalities in the labor market (Ehrenreich and Hochschild 2002; Glenn 1992; Milkman, Reese, and Roth 1998; Parreñas Salazar 2014).

Similarly Hobson and Bede (2015) suggest that the diverse backgrounds and situations of domestic and care workers shape their capabilities and possibilities to influence their income and working conditions. Several other studies support these findings, arguing that the individual characteristics of the worker may influence the bargaining power related to the job, and thus improve their working conditions (Anderson 2000; Gurung 2009; van Walsum 2011). Migrant care workers, especially undocumented migrants, are often identified as a disadvantaged group in the labor markets (Anderson 2010; 
Behtoui et al. 2016; Parreñas Salazar 2000; Shutes and Walsh 2012). In addition, institutional context, particularly market-oriented policies, may also contribute to the division of race, ethnicity, and citizenship in care-related services (Shutes and Walsh 2012). An employee's age may also affect the level of precarity in a job. Young employees usually have lower earnings, are generally more likely to work in jobs that are temporary or part-time, and thus, more likely to work in precarious employment settings (Cranford, Vosko, and Zukewich 2003; Rueda 2007).

In light of previous studies discussed above, the current study poses the following hypotheses:

Hypothesisla: Persons working in care-related industries are more likely to work under precarious working conditions than other workers

Hypothesis 1b: The association is stronger between paid domestic work and precarious employment compared to care industries

Hypothesis 2: Demographic factors, such as being a woman, of younger age and immigrant, are associated with higher risk of employment precariousness

Hypothesis 3: The association between precarious work and the two care-related industries (paid domestic work and care work) is expected to be stronger in welfare regimes with poorer labor market regulation and where paid domestic labor is less regulated.

\section{Data, Variables, and Methods}

This analysis uses the wave IX (2013/2014) of the LIS. The sample consists of employed individuals who are between 18 and 64 years old, and not in military service. The LIS collects and harmonizes microdatasets from a number of upper- and middle-income countries. ${ }^{2}$ The datasets include householdand personal-level information on income, labor market outcomes, and public transfers and taxes. Since the datasets are harmonized, the LIS data fits particularly well for comparative analysis. However, some of the variables (e.g. migrant status, ethnicity, and wage) might vary from country to country, as they may be differently defined depending on the dataset. This point is taken into consideration in analysis of the results.

The advantage of household surveys is that the samples are usually representative of all households in a country. In addition, the data cover both declared and undeclared work, regardless whether it is performed in a formal or informal economy, depending of course on the willingness of the respondents to report undeclared work (ILO 2013, 13). However, the LIS does not capture undocumented migrant workers, who are commonly in paid domestic services, which should be kept in mind while interpreting the results. 
Nevertheless, there is a fairly large share of registered domestic workers in all countries examined, which is why household data still provide a reference for the employment patterns of persons employed in domestic services.

\section{Dependent Variable: Precarious Employment}

As noted above, here precarious employment is understood as a set of employment conditions identified in previous studies as contributing to uncertainty and insecurity for an individual in the labor market (Prosser 2016; Pyöriä and Ojala 2016; Rodgers and Rodgers 1989; Vosko 2006). These include (i) part-time employment ( 0 = full-time, $1=$ part-time), (ii) unemployment experience during the past year $(0=$ no, $1=$ yes $)$, (iii) job tenure $(0=$ more than 1 year, $1=1$ year or less), and (iv) low-wage work $(0=$ no, $1=$ yes). Unemployment experience and short job tenure are both viewed as dimensions of precarity that measure job instability. Low wage is considered as a feature of precarious employment as it does not provide a living wage for the employee in the given country. For low-wage work, the OECD definition of low pay was used, which counts individuals earning less than two-thirds of median earnings as low-wage workers (OECD 2015b, 172). Data on wages are based on hourly wage. The wage variable is adjusted to extreme values, that is, bottom-coded at $1 \%$ of mean income and top-coded at 10 times the median income. For most domestic workers in the data, domestic work was reported as the only source of earnings: the percentage of workers holding a second job was 1.8 in Spain, 3.7 in Luxembourg, 4 in Italy, 4.3 in the United States, and 9.9 in Germany.

Countries in the LIS data have two different approaches to measuring wages, which is why for Spain, the United States, and Germany, the hourly wage is available as gross wage (before deduction of taxes and social contributions) and for Italy and Luxembourg, as net wage (after deduction of taxes and social contributions). Although, for the latter, the individual's total wage amount is not known, this should not influence the overall results, as the aim of the analysis is primarily to compare the level of precariousness between groups of workers and not to analyze the level of wages across countries.

For the multivariate analysis, this study forms a sum variable of three to four dummy variables of precarious employment with a scale from 0 to 3 or 0 to 4 depending on the availability of the two indicators measuring job instability (unemployment experience and job tenure): the analysis for Italy only covers three indicators (part-time employment, low wage and job tenure) since information on unemployment experience was not available. In contrast, the data for Spain and the United States do not include information on job tenure, which is why precarious employment comprises part-time employment, low wage, and unemployment experience. For Germany and Luxembourg, all four indicators are covered. 


\section{Key Independent Variables}

The key independent variable compares individuals employed in paid domestic work to care work and other industries. All information regarding employment characteristics, including the industry, is based on the informant's main job. Following the approach used by the ILO (2013) and several previous studies, domestic workers are defined as persons employed by a household performing domestic and care work in the household. The analysis relies on the industry-based approach based on ISIC (International Standard Industrial Classification of All Economic Activities) Revision 4, defining all persons employed by private households as domestic workers. This definition was chosen as it is the most consistent for the household data used in the study; only a few countries provide disaggregated information on specific occupations. This means that the analysis excludes domestic workers who are employed by private enterprises. While this group has similarities with domestic workers employed by a household, it is widely argued that the employment relationship (household as employer) puts the latter group in the most vulnerable position in the labor markets. While the industry-based approach allows for a more comprehensive cross-national comparison, it also excludes countries in the Nordic regime (in wave IX of the LIS data these are Finland and Denmark), since the number of persons employed by private households in the two datasets is too low for reliable estimates (Finland 20 and Denmark 37).

The second industry group used in the study is care work. Several approaches have been used to define care work, varying from occupational classifications (Duffy 2005; England, Budig, and Folbre 2002) and combinations of occupation and industry (Budig and Misra 2010; England, Budig, and Folbre 2002; Lightman 2017) to wider concepts of care work as industry or sector (Duffy, Albelda, and Hammonds 2013; England, Budig, and Folbre 2002). England, Budig, and Folbre $(2002,459)$ define care work as "giving a face-to-face service to a client or customer of the organization in which one is employed which increases the capabilities of this recipient." This approach entails direct or interactive care work, such as childcare or health care, but also helping professions, such as social workers, therapists, or clergy. Moreover, other studies suggest that care work comprises all activities involved in social reproduction, including tasks considered as indirect care, such as cleaning, preparing meals, and cleaning sheets (Budlender, 2008; Duffy, 2005).

This study follows the approach used by England, Budig, and Folbre (2002) and Budig and Misra (2010) that combines industry and occupation in order to identify care workers. Two ISIC industry categories, education and health care, are considered as care work. Occupational categories are used to identify care work that entails both face-to-face service and increases the capabilities of the recipient. However, in order to stay consistent with the 
definition of domestic work, occupations such as housekeepers and cleaners are counted as care work. To identify care workers, the categories are formed as specifically as possible. Hence a care worker has to both work in a care industry and in a care occupation in order to be included in the category of care work (see appendix 1 for detailed categories). The exception in this analysis is Italy, where disaggregated data on occupations were unfortunately not available and care work is defined only by industry. Managers and professionals (ISCO categories 1 and 2) were excluded from the category of care workers, as, according to previous studies, medical and education professionals (such as doctors and teachers) may be seen as holding a higher "social closure," and hence are in a better position to negotiate employment benefits and conditions compared to other caring occupations (Lightman 2017; Weeden 2002). These occupations are included in the third general group (other industries) along with all other occupations.

\section{Control Variables}

Following earlier studies on the role of human capital and intersectional identities in the labor markets (Duffy, Albelda, and Hammonds 2013; England 2005), demographic and family variables were added in the multivariate regression analysis (table 1). These include gender, age, ethnicity (only for the United States), migrant status, education, presence of children under 6 years old, and living with partner. Previous studies have found that family characteristics, such as marital status and having children, may have negative implications for employment opportunities because they may influence the time and effort one can dedicate to work (Greenhaus and Beutell 1985; Young 2010). Higher human capital, here measured as education, is found to decrease the risk of precarious employment (Becker 1994; Kalleberg 2000). Furthermore, the last model also controls for sector of employment, ${ }^{3}$ as public sector employees are found to have more stable jobs compared to private sector (Leschke 2015). In the LIS database, variables for migrant status are defined slightly differently, depending on the dataset: nationality (Italy, Luxembourg, and Germany), country of birth (Spain), or neither nationality or country of birth is the one where they reside (United States). Due to the large cross-border migration of higher skilled workers from neighboring countries to Luxembourg (see OECD 2015a), German, Dutch, French, and Belgian respondents were not coded as migrants. Furthermore, particularly in the United States, ethnic background is shown to be strongly linked with the inequalities in paid domestic labor (Glenn 1992; Milkman, Reese, and Roth 1998), which is why for the United States there is control for ethnicity $(0=$ white, $1=$ nonwhite $)$. However, this information was not available for European countries. 


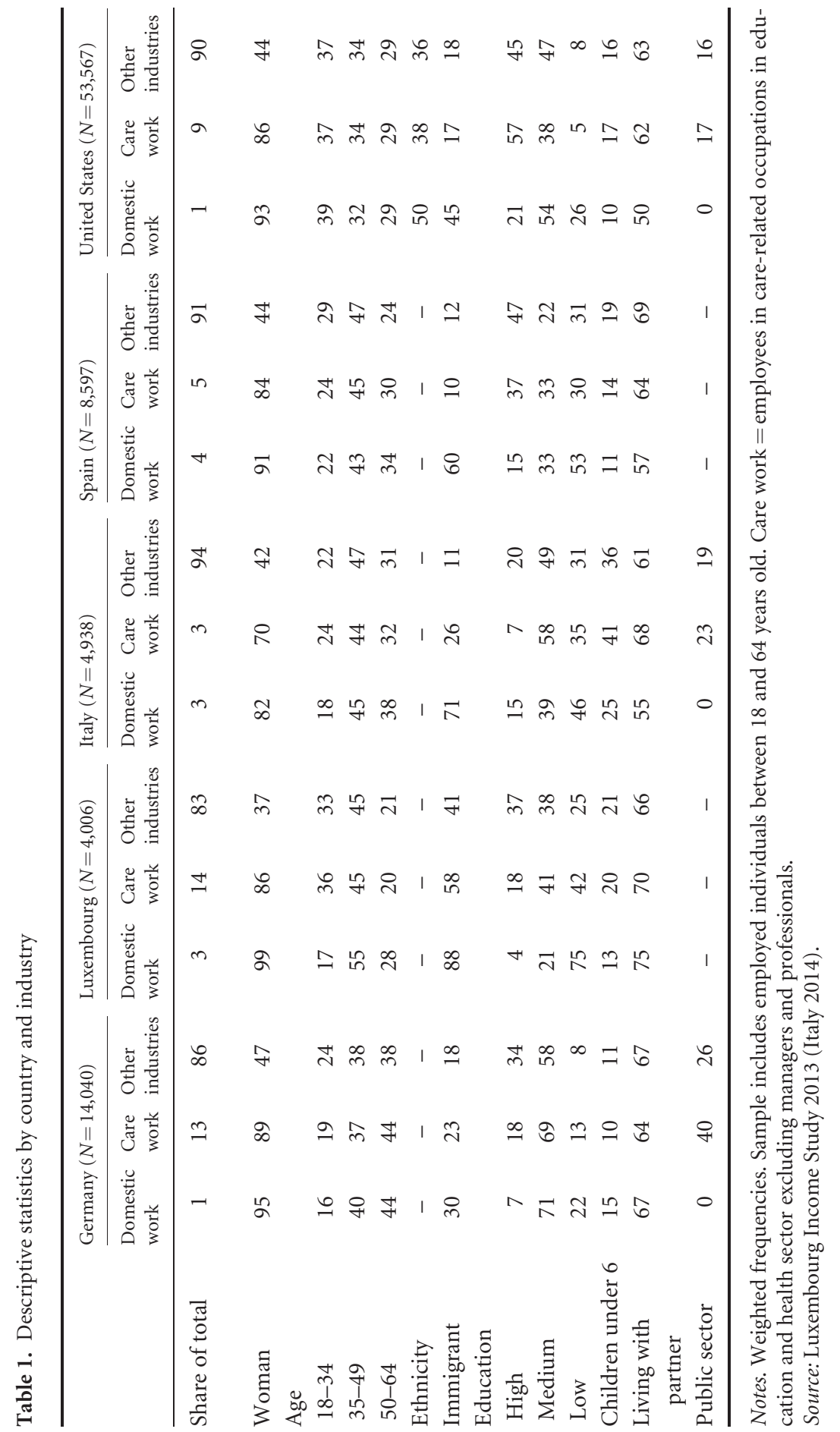




\section{Analytical Strategy}

The empirical section consists of two parts. The first part consists of crosstabulations on the patterns and levels of precarious employment conditions. In the second part, regression analysis is run to examine the factors associated with precarious employment, and in particular, the impact of industry and individual characteristics on precarious employment conditions.

Ordered logistic regression was used to analyze the data for all five datasets separately. The regression analysis was run with four models, where model 1 presents the effect of industry on precarious employment controlled for gender. Model 2 adds the individual-level and family variables in the analysis, followed by model 3, which includes education. Model 4 controls for type of sector (public/private).

\section{Results}

\section{Dimensions of Precarious Employment in Domestic Work and the Care Work Industry}

Before analyzing the factors associated with precarious work settings, we look at the patterns of precarity for the two female-dominated industries (table 2). Domestic workers score high in all indicators, while the situation of care workers varies depending on country and dimension. In all five countries, more than half of domestic workers hold part-time jobs. The exceptionally high figure in Germany may partly be explained by the Mini Job system, which is widely used in paid domestic work. According to the LIS data (not shown here), 68 percent of domestic workers are "mini-jobbers." In Germany, Italy, and United States, job instability (measured by unemployment experience during last year in the United States, short job tenure in both Italy and Germany) is more frequent among domestic workers than among other industries. In Spain, unemployment spells are equally common among domestic workers compared to other industries, which may be related to the generally high job instability caused by the economic crisis. In the case of Luxembourg, where job instability is measured by short job tenure, the relatively small differences may be due to the fact that short-term employment in Luxembourg is very low in general, and temporary contracts are strictly regulated.

Overlaps between the three dimensions of precarious employment can help identify differences in the level of precariousness. Figure 1 shows the proportion of individuals who hold a job with one to four dimensions of precarious employment (or none). Workers in paid domestic work are more likely to hold jobs with two or more dimensions of precarity in all countries studied, and these numbers are particularly high in Germany and Spain. Care work is less affected by overlaps in Italy, Spain, and the United States and more precarious in Germany and Luxembourg. 


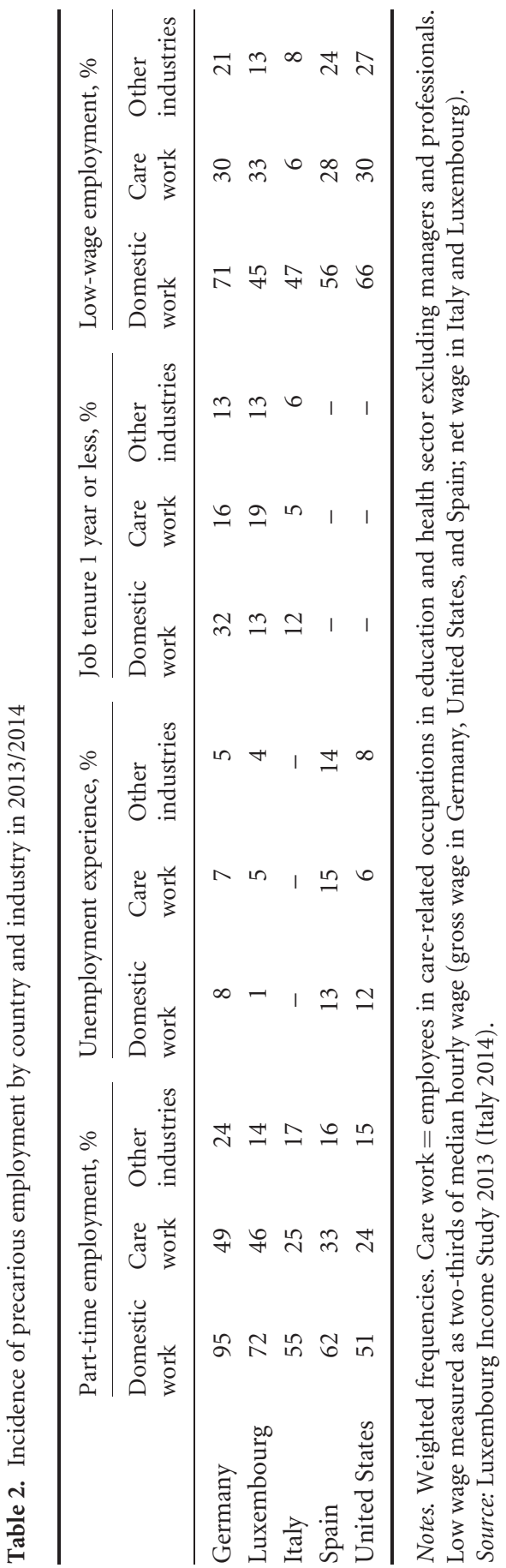



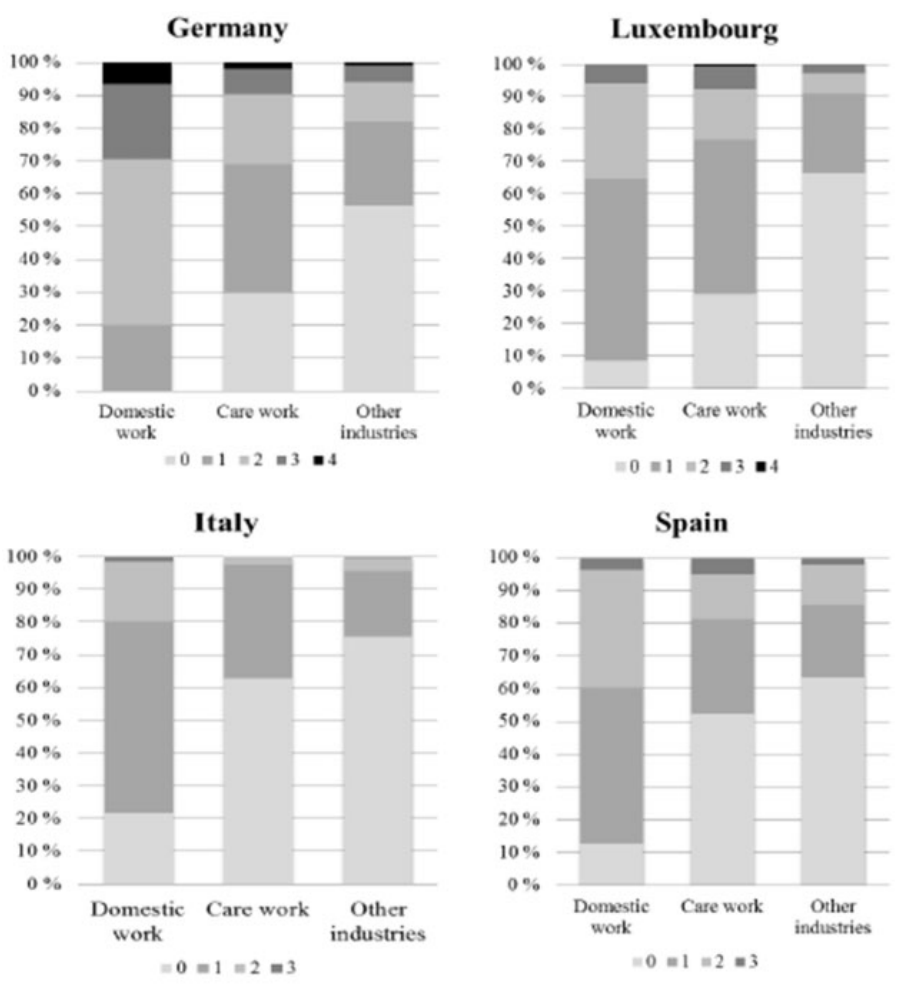

US

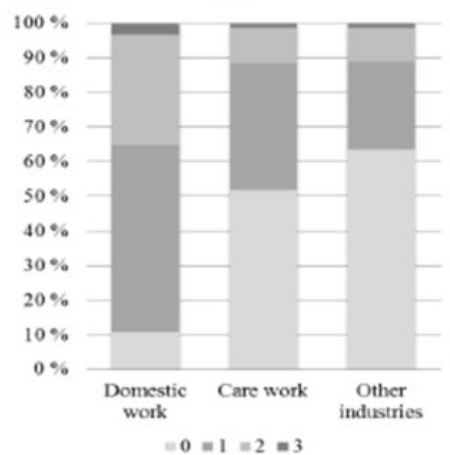

Figure 1. Proportion of individuals holding a job with 0 to 4 dimensions of precarious employment by industry 2013/2014, \%. 
Table 3. Multivariate regression analysis on precarious employment

\begin{tabular}{|c|c|c|c|c|c|}
\hline & & Model 1 & Model 2 & Model 3 & Model 4 \\
\hline Germany & Care work & $0.414^{* * *}$ & $0.420^{\star * *}$ & $0.301^{\star * *}$ & $0.394^{\star * *}$ \\
\hline$N=13,794$ & Domestic work & $1.92^{\star * *}$ & $1.894^{\star * *}$ & $1.838^{\star * *}$ & $1.729^{* * *}$ \\
\hline Luxembourg & Care work & $1.024^{\star \star \star}$ & $0.960^{* * *}$ & $0.780^{\star * *}$ & - \\
\hline$N=3,977$ & Domestic work & $1.593^{\star * *}$ & $1.563^{* * *}$ & $1.264^{\star * *}$ & - \\
\hline Italy & Care work & 0.28 & 0.291 & 0.144 & 0.214 \\
\hline$N=4,934$ & Domestic work & $1.769^{\star * *}$ & $1.711^{\star * *}$ & $1.538^{\star \star *}$ & $1.436^{\star * *}$ \\
\hline Spain & Care work & 0.176 & $0.254^{\star *}$ & 0.163 & - \\
\hline$N=8,539$ & Domestic work & $1.361^{\star * *}$ & $1.277^{\star * *}$ & $0.947^{\star \star *}$ & \\
\hline United States & Care work & $0.180^{\star * *}$ & $0.206^{* * *}$ & $0.336^{* * *}$ & $0.330^{* * *}$ \\
\hline$N=53,567$ & Domestic work & $1.562^{\star * *}$ & $1.420^{\star * *}$ & $1.165^{\star * *}$ & $1.118^{\star * *}$ \\
\hline
\end{tabular}

${ }^{*} \mathrm{p}<0.05,{ }^{* *} \mathrm{p}<0.01,{ }^{* * *} \mathrm{p}<0.001$

Notes. Model 1 includes gender; Model 2 includes demographics and family structure (age, migrant status, ethnicity (only United States), cohabitation, and presence of young children); Model 3 includes education level; Model 4 ads sector of employment. See appendix 2 for full results.

\section{The Role of Industry and Individual Characteristics in Explaining Precarious Employment}

An ordered logistic regression was conducted to examine the association between industry and the likelihood of working in precarious employment settings (table 3). Earlier research suggests that female-dominated care labor is associated with more precarity than other industries and particularly lowskilled care jobs tend to suffer from a wage penalty (Lightman 2017; Budig and Misra 2010; England, Budig, and Folbre 2002). Model 1 partly supports the first (1a) hypothesis as both working in the care industry and paid domestic services were associated with a higher level of precarious employment in Germany, Luxembourg, and the United States. In the two Mediterranean countries, Italy and Spain, workers in care industry were not more likely to work under precarious employment settings compared to other industries. The association between paid domestic work and precarious employment remained unchanged in all five countries, even after controlling for all background variables, which confirms hypothesis $1 \mathrm{~b}$.

The results also partly support the second hypothesis, as women and younger individuals were more likely to hold jobs with precarious employment settings compared to men and older employees (see appendix 2). Similarly, immigrant status was associated with higher precarity in all five countries. Lastly, working in the public sector has earlier been linked with less precarious employment conditions (Leschke 2015; Young 2010). The results fully confirmed this hypothesis across countries except Spain and Luxembourg, where 


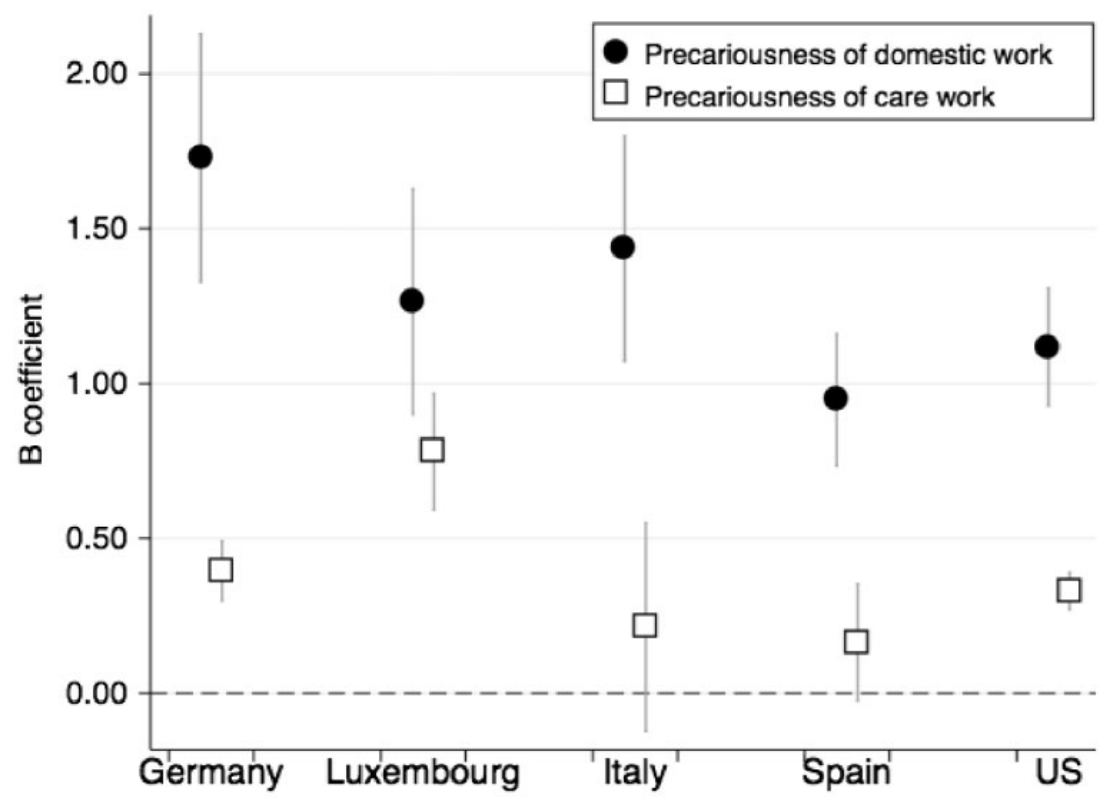

Figure 2. Association between precarious employment conditions and domestic work and care work (95\% confidence intervals).

the variable was not included in the dataset. Lastly, the association between family characteristics and precarious employment conditions varied between welfare states. In Continental welfare states, the presence of small children increased the risk of working in precarious employment settings, while in the United States it had an opposite effect. In Mediterranean countries, no association was found between the presence of small children and precarious employment. Living with a partner was negatively associated with job precarity in all countries.

An additional analysis was conducted to test whether the strength of the association between paid domestic labor and precarious employment differs between welfare regimes (figure 2). The association of domestic work with precariousness was stronger in the two Continental countries $(B=1.47,95 \%$ $\mathrm{CI}=1.21,1.74$ for a weighted average of Germany and Luxembourg) than in the two Mediterranean countries $(B=1.07,95 \% \mathrm{CI}=0.89,1.26$ for a weighted average of Italy and Spain) and the United States $(B=1.12,95 \%$ $\mathrm{CI}=0.93,1.31$ ). The confidence intervals of the two latter estimates did not overlap with the point estimate of the Continental regime, indicating that the difference was statistically significant whereas the difference between the Mediterranean regime and the United States was not. 


\section{Discussion and Conclusion}

The aim of this study was to explore the effect of industry and individual characteristics on precarious employment settings in different welfare regimes. This is the first quantitative comparative study that examines the relationship between paid domestic labor and precarious employment on the microlevel. To capture the phenomenon of precarious employment, the analysis concentrated on a set of employment conditions that included part-time employment, job instability (unemployment experience and/or job tenure), and low pay formed as one indicator. Such a multidimensional approach may provide a more comprehensive understanding on the patterns of precarity compared to a singular focus on wages or nonstandard employment.

While there are notable differences among the five welfare states regarding general prevalence of precarious employment settings, domestic work is associated with higher levels of precarity compared to other industries across welfare regimes and regardless of the institutional settings. The association remained unchanged even after controlling for a set of background variables. The results support the previous qualitative comparisons that highlight the convergence of domestic workers' precarious position in the labor markets (Hellgren 2015; Hobson, Hellgren, and Bede 2015; Williams 2012). Furthermore, the overlaps of two or more precarious employment settings were significantly more common in paid domestic work than among other industries in all countries studied. This is a significant finding, as it proves the high insecurity of the formal paid domestic labor industry not only in the liberal welfare regime (here the United States) where markets for domestic services are poorly regulated but even in countries with specific regulations regarding paid domestic labor. In fact, contrary to the hypothesis, the association between paid domestic work and precarious employment did not follow the welfare regime pattern; the association was not strongest in the liberal welfare state (United States) but in the Continental European welfare states Germany and Luxembourg. However, in order to analyze the robust comparison between regimes, more countries should be included in the analysis.

Moreover, as previous studies (Jokela 2017; Morel 2015; van Walsum 2011) show, policies targeted toward domestic services may even increase the precarity of the sector. The results of the instant analysis support this finding in the case of Germany, where the domestic labor sector is comprised largely of "Mini Job" holders and both high levels of nonstandard and low pay. The findings also highlight the duality of the German labor market where a large majority of domestic workers experienced overlaps in precarious employment conditions while an equally large share of workers in other industries did not.

The results also partly support the devaluation thesis, as working in the (low status) care industry was associated with precarious employment in 
Germany, Luxembourg, and the United States. However, as hypothesized, the effect was not as strong as for domestic work. In contrast, in Italy and Spain, no significant association was found between care industry and precarious employment. This does not mean that care workers do not face precarious employment conditions but rather it may reflect the complexity of precarious work and its different dimensions in different institutional settings. For instance, the differences between care industry and other industries in the prevalence of low-wage work measured in relative terms are fairly small in both Italy and Spain, which may have to do with the generally low wage levels in these countries. Moreover in Spain, the recent economic crisis has led to increased levels of job instability across industries, not only in care-related jobs (Hellgren and Serrano 2017; Prosser 2016).

Lastly, the results confirm the second hypothesis concerning the impact of social categories on precarious employment, which was similar across welfare states. Being a woman, younger of age, lower educated, and immigrant all increased the risk of working in precarious employment settings. This result supports earlier findings on migrants' weaker position in labor markets (Behtoui et al. 2016; Meagher, Szebehely, and Mears 2016), which would certainly have been even worse had undocumented migrants been included in the data.

As always, one should take into account the data and its limitations when interpreting the results. Since the analysis only focused on the main job of the individual, some information, such as income precariousness, could not be fully captured since information on other jobs was excluded from the analysis. Thus, the analysis presents the precariousness of employment settings in one's job rather than the overall precariousness of an individual. Due to the differences regarding some of the variables, the results are not fully comparable across countries. However, while relevant, this is of less concern in this study, as the main focus was on precarity of domestic work in relation to other industries and the comparison of this relationship across countries, rather than on comparing the level of precarious employment in general.

A more important question is the definition of precarious employment and its impact on the results. In this study, precarity was measured by objective indicators that are typically used when identifying uncertain, nonstandard, and low-wage relationships. The analysis did not include any subjective measures related to job precarity or quality that could provide a more complex picture of the phenomenon. It should also be acknowledged that there are issues related to individual characteristics and social location that cannot be captured in this study, meaning that not all precarious workers are equally vulnerable. Paid domestic work offers employment opportunities and path for migration for a large number of (mostly) women, and many of them may possess capabilities, bargaining power, or informal networks that reduce their risk of precarity. Furthermore, there are occupational differences 
inside the domestic service and care industry that could not be studied separately in this paper.

However, as this study indicates, despite the individual differences, there is an unexplained and persistent effect that links domestic workers with inequality across welfare regimes, which seems to be rather structural. Domestic service is promoted across affluent countries as one of the growing sectors of employment that is supposed to provide job opportunities particularly for women, lower-educated individuals, and migrants. However, as the results showed, these social categories are both overrepresented in domestic work industry and have a higher risk of working in nonstandard employment settings with high job instability and low wages. In order to understand the specific consequences of these risks, further research is needed on the complex patterns of precarity inside the domestic and care labor sector.

\section{Appendix 1 Definition of care work}

\begin{tabular}{|c|c|c|c|}
\hline Country & Industry code & $\begin{array}{l}\text { Occupation } \\
\text { code }\end{array}$ & $\begin{array}{l}\text { Occupation (ISCO skill } \\
\text { levels 3-9), \% }\end{array}$ \\
\hline Germany & $\begin{array}{l}\text { 17-category ISIC } 3.1 \\
\text { recode: Education; } \\
\text { Health and social work }\end{array}$ & $\begin{array}{l}\text { ISCO- } 88 \\
\text { occupation } \\
\text { code }\end{array}$ & $\begin{array}{l}\text { - Life science and health } \\
\text { associate professionals, } \\
22\end{array}$ \\
\hline Luxembourg & $\begin{array}{l}21 \text { category ISIC } 4 \text { recode: } \\
\text { Education; Human } \\
\text { health and social work } \\
\text { activities }\end{array}$ & $\begin{array}{l}\text { ISCO-08 } \\
\text { occupation } \\
\text { code }\end{array}$ & $\begin{array}{l}\text { - Teaching associate } \\
\text { professionals, } 17 \\
\text { - Other associate } \\
\text { professionals, } 11 \\
\text { - Personal care and } \\
\text { related workers } 24 \\
\text { - Cleaners and helpers, } \\
26 \\
\text { - Health associate } \\
\text { professionals, } 11 \\
\text { - Legal, social, cultural } \\
\text { and related associate } \\
\text { professionals, } 16 \\
\text { - Personal care workers, } \\
15 \\
\text { - Cleaners and helpers, } \\
51 \\
\text { - Food preparation } \\
\text { assistants, } 8\end{array}$ \\
\hline
\end{tabular}

Continued 


\section{Continued}

\begin{tabular}{|c|c|c|c|}
\hline Country & Industry code & $\begin{array}{l}\text { Occupation } \\
\text { code }\end{array}$ & $\begin{array}{l}\text { Occupation (ISCO skill } \\
\text { levels 3-9), \% }\end{array}$ \\
\hline Italy & $\begin{array}{l}21 \text { category ISIC } 4 \text { recode: } \\
\text { Education; Human } \\
\text { health and social work } \\
\text { activities }\end{array}$ & $\begin{array}{l}\text { National } \\
\text { classification }\end{array}$ & $\begin{array}{l}\text { Blue-collar worker or } \\
\text { similar, } 100\end{array}$ \\
\hline Spain & $\begin{array}{l}21 \text { category ISIC } 4 \text { recode: } \\
\text { Education; Human } \\
\text { health and social work } \\
\text { activities }\end{array}$ & $\begin{array}{l}\text { ISCO-08 } \\
\text { occupation } \\
\text { code }\end{array}$ & $\begin{array}{l}\text { - Health associate } \\
\text { professionals, } 53 \\
\text { - Legal, social, cultural } \\
\text { and related associate } \\
\text { professionals, } 5 \\
\text { - Personal care workers, } \\
25 \\
\text { - Cleaners and helpers, } \\
16 \\
\text { - Food preparation } \\
\text { assistants, } 2\end{array}$ \\
\hline United States & $\begin{array}{l}\text { 17-category ISIC } 3.1 \\
\text { recode: Education; } \\
\text { Health and social work }\end{array}$ & $\begin{array}{l}2010 \\
\text { Census } \\
\text { code }\end{array}$ & $\begin{array}{l}\text { - Community and social } \\
\text { service occupation, } 2 \\
\text { - Education, training, } \\
\text { and library occupation, } \\
10 \\
\text { - Healthcare practi- } \\
\text { tioners and technical } \\
\text { occupations, } 47 \\
\text { - Health care support } \\
\text { occupations, } 26 \\
\text { - Food preparation and } \\
\text { serving related } \\
\text { occupations, } 1 \\
\text { - Maids and housekeep- } \\
\text { ing cleaners, } 3 \\
\text { - Personal care and } \\
\text { service occupation, } 11\end{array}$ \\
\hline
\end{tabular}




\section{Appendix 2 Models by country}

Germany 2013: Multivariate regression analysis on precarious employment

\begin{tabular}{|c|c|c|c|c|}
\hline & Model 1 & Model 2 & Model 3 & Model 4 \\
\hline Care workers & $0.414^{\star * *}$ & $0.420^{\star * *}$ & $0.301^{* * *}$ & $0.394^{* * *}$ \\
\hline Domestic workers & $1.92^{* * *}$ & $1.894^{* * *}$ & $1.838^{\star \star \star}$ & $1.729^{\star * *}$ \\
\hline Woman & $1.371^{\star * *}$ & $1.437^{\star * *}$ & $1.509^{\star * *}$ & $1.604^{\star * *}$ \\
\hline \multicolumn{5}{|l|}{ Age (18-34) } \\
\hline $35-49$ & & $-0.712^{\star * *}$ & $-0.615^{\star * *}$ & $-0.591^{\star * *}$ \\
\hline $50-64$ & & $-0.841^{\star \star *}$ & $-0.731^{\star * *}$ & $-0.698^{\star * *}$ \\
\hline Immigrant & & $0.469^{* * *}$ & $0.332^{* * *}$ & $0.295^{\star * *}$ \\
\hline Children under 6 & & $0.106^{\star}$ & $0.192^{\star * *}$ & $0.1919^{\star *}$ \\
\hline Living with partner & & $-0.247^{\star * *}$ & $-0.156^{\star * *}$ & $-0.156^{\star * *}$ \\
\hline \multicolumn{5}{|l|}{ Education (high) } \\
\hline Medium & & & $0.724^{\star \star \star}$ & $0.632^{\star * *}$ \\
\hline Low & & & $1.439^{* * *}$ & $1.312^{* * *}$ \\
\hline Sector (public) & & & & $0.606^{\star * *}$ \\
\hline Observations & 13,954 & 13,954 & 13,693 & 13,570 \\
\hline Pseudo $R^{2}$ & 0.063 & 0.084 & 0.102 & 0.111 \\
\hline
\end{tabular}

Luxembourg 2013: Multivariate regression analysis on precarious employment

\begin{tabular}{|c|c|c|c|}
\hline & Model 1 & Model 2 & Model 3 \\
\hline Care workers & $1.024^{\star * *}$ & $0.960^{* * *}$ & $0.780^{* * *}$ \\
\hline Domestic workers & $1.593^{\star * *}$ & $1.563^{\star * *}$ & $1.264^{* * *}$ \\
\hline Gender (woman) & $0.912^{\star * *}$ & $0.994^{\star * *}$ & $1.095^{\star * *}$ \\
\hline \multicolumn{4}{|l|}{ Age (18-34) } \\
\hline $35-49$ & & $-0.533^{\star * *}$ & $-0.583^{* * *}$ \\
\hline $50-64$ & & $-0.592^{\star \star *}$ & $-0.706^{\star * *}$ \\
\hline Immigrant & & $0.502^{\star \star *}$ & $0.293^{\star * *}$ \\
\hline Children under 6 & & $0.200^{\star}$ & $0.025^{\star}$ \\
\hline Living with partner & & $-0.388^{\star \star \star}$ & $-0.363^{* * *}$ \\
\hline \multicolumn{4}{|l|}{ Education (high) } \\
\hline Medium & & & $0.416^{\star * *}$ \\
\hline Low & & & $0.938^{* * *}$ \\
\hline Observations & 3,980 & 3,980 & 3,941 \\
\hline Pseudo $R^{2}$ & 0.069 & 0.090 & 0.103 \\
\hline
\end{tabular}


Patterns of Precarious Employment in a Female-Dominated Sector

Italy 2014: Multivariate regression analysis on precarious employment

\begin{tabular}{|c|c|c|c|c|}
\hline & Model 1 & Model 2 & Model 3 & Model 4 \\
\hline Care workers & 0.28 & 0.291 & 0.144 & 0.214 \\
\hline Domestic workers & $1.769^{* * *}$ & $1.711^{\star \star \star}$ & $1.538^{* * *}$ & $1.436^{\star * *}$ \\
\hline Woman & $0.89^{* * *}$ & $1.012^{\star * *}$ & $1.18^{\star \star *}$ & $1.231^{\star * *}$ \\
\hline \multicolumn{5}{|l|}{ Age (18-34) } \\
\hline $35-49$ & & $-0.999^{* * *}$ & $-1.092^{\star * *}$ & $-1.018^{\star * *}$ \\
\hline $50-64$ & & $-1.540^{* * *}$ & $-1.675^{\star \star *}$ & $-1.491^{\star * *}$ \\
\hline Immigrant & & $0.425^{\star * *}$ & $0.341^{\star \star}$ & $0.251^{\star *}$ \\
\hline Children under 6 & & -0.047 & -0.016 & -0.025 \\
\hline Living with partner & & $-0.220^{*}$ & $-0.244^{* *}$ & $-0.196^{*}$ \\
\hline \multicolumn{5}{|l|}{ Education (high) } \\
\hline Medium & & & $0.511^{\star * *}$ & $-0.327^{\star *}$ \\
\hline Low & & & $1.110^{* * *}$ & $0.823^{\star * *}$ \\
\hline Sector (public) & & & & $1.142^{\star * *}$ \\
\hline Observations & 4,934 & 4,934 & 4,934 & 4,934 \\
\hline Pseudo $R^{2}$ & 0.047 & 0.101 & 0.117 & 0.132 \\
\hline
\end{tabular}

Spain 2013: Multivariate regression analysis on precarious employment

\begin{tabular}{|c|c|c|c|}
\hline & Model 1 & Model 2 & Model 3 \\
\hline Care workers & 0.176 & $0.254^{\star \star}$ & 0.163 \\
\hline Domestic workers & $1.361^{\star * *}$ & $1.277^{\star \star \star}$ & $0.947^{\star \star \star}$ \\
\hline Woman & $0.659^{* * *}$ & $0.689^{* * *}$ & $0.887^{\star \star \star}$ \\
\hline \multicolumn{4}{|l|}{ Age (18-34) } \\
\hline $35-49$ & & $-0.897^{\star * \star}$ & $-0.953^{\star * *}$ \\
\hline $50-64$ & & $-1.303^{* * *}$ & $-1.487^{\star * *}$ \\
\hline Immigrant & & $0.653^{\star * *}$ & $0.060^{* * *}$ \\
\hline Children under 6 & & $0.160^{\star *}$ & -0.072 \\
\hline Living with partner & & $-0.208^{\star * *}$ & $-0.226^{\star * *}$ \\
\hline \multicolumn{4}{|l|}{ Education (high) } \\
\hline Medium & & & $0.578^{\star \star \star}$ \\
\hline Low & & & $1.254^{\star \star \star}$ \\
\hline Observations & 8,539 & 8,539 & 8,535 \\
\hline Pseudo $R^{2}$ & 0.03 & 0.070 & 0.100 \\
\hline
\end{tabular}


United States 2013: Multivariate regression analysis on precarious employment

\begin{tabular}{|c|c|c|c|c|}
\hline & Model 1 & Model 2 & Model 3 & Model 4 \\
\hline Care workers & $0.180^{* * *}$ & $0.206^{\star * *}$ & $0.336^{* * *}$ & $0.330^{\star * *}$ \\
\hline Domestic workers & $1.562^{* * *}$ & $1.420^{* * *}$ & $1.165^{\star * *}$ & $1.118^{\star * *}$ \\
\hline Woman & $0.542^{\star * *}$ & $0.570^{* * *}$ & $0.702^{\star * *}$ & $0.722^{* * *}$ \\
\hline \multicolumn{5}{|l|}{ Age (18-34) } \\
\hline $35-49$ & & $-0.902^{\star \star *}$ & $-0.871^{\star * \star}$ & $-0.854^{* * *}$ \\
\hline $50-64$ & & $-0.941^{\star \star *}$ & $-0.955^{\star * *}$ & $-0.924^{* * *}$ \\
\hline Ethnicity: nonwhite & & $0.230^{* * *}$ & 0.037 & $-0.051^{\star}$ \\
\hline Immigrant & & $0.282^{\star * *}$ & $0.119^{* * *}$ & $0.088^{\star *}$ \\
\hline Children under 6 & & $-0.262^{\star * \star}$ & $-0.243^{\star * *}$ & $-0.242^{* * *}$ \\
\hline Living with partner & & $-0.586^{* * *}$ & $-0.521^{* * *}$ & $-0.516^{* * *}$ \\
\hline \multicolumn{5}{|l|}{ Education (high) } \\
\hline Medium & & & $1.001^{\star * \star}$ & $0.964^{* * *}$ \\
\hline Low & & & $1.700^{\star * *}$ & $1.644^{\star * *}$ \\
\hline Sector (public) & & & & $0.400^{\star * *}$ \\
\hline Observations & 53,567 & 53,567 & 53,367 & 53,367 \\
\hline Pseudo $R^{2}$ & 0.014 & 0.063 & 0.100 & 0.119 \\
\hline
\end{tabular}

\section{Notes}

Merita Jokela is a researcher at the National Institute for Health and Welfare and a PhD researcher at the Department of Social Research, University of Turku. Her research interests include comparative policy research and issues related to gender and employment. Her PhD dissertation deals with the politics of paid domestic labor and the status of domestic workers in the labor markets in comparative perspective.

1. See http://www.guichet.public.lu/entreprises/en/sante-securite/declarationsecu/immatriculation/menage-prive/index.html.

2. For more information, see www.lisdatacenter.org.

3. Not available for Spain and Luxembourg.

\section{Acknowledgments}

I would like to thank Susan Kuivalainen, Markus Jokela, and Veli-Matti Ritakallio for their comments in the writing of this article. I also thank two anonymous reviewers whose comments greatly helped to improve an earlier version of this manuscript. This article has benefited from the Finnish Cultural Foundation. 


\section{References}

Anderson, Bridget. 2000. Doing the dirty work? The global politics of domestic labour. London: Palgrave Macmillan.

- 2007. A very private business: Exploring the demand for migrant domestic workers. European Journal of Women's Studies 14 (3): 247-64.

- 2010. Migration, immigration controls and the fashioning of precarious workers. Work, Employment \& Society 24 (2): 300-317.

Avril, Christelle, and Marie Cartier. 2014. Subordination in home service jobs: Comparing providers of home-based child care, elder care, and cleaning in France. Gender \& Society 28 (4): 609-30.

Becker, Gary. 1994. Human capital: A theoretical and empirical analysis, with special reference to education. Chicago: University of Chicago Press.

Behtoui, Alireza, Kristina Boréus, Anders Neergaard, and Soheyla Yazdanpanah. 2016. Speaking up, leaving or keeping silent: Racialized employees in the Swedish elderly care sector. Work, Employment \& Society 31 (6): 1-18.

Bettio, Francesca, Annamaria Simonazzi, and Paola Villa. 2006. Change in care regimes and female migration: The 'care drain' in the Mediterranean. Journal of European Social Policy 16 (3): 271-85.

Bowman, John R., and Alyson M. Cole. 2014. Cleaning the 'people's home': The politics of the domestic service market in Sweden. Gender, Work \& Organization 21 (2): 187-201.

Budig, Michelle, and Joya Misra. 2010. How care-work employment shapes earnings in cross-national perspective. International Labour Review 149 (4): 441-60.

Budlender, Debbie. 2008. The statistical evidence on care and non-care work across six countries. Gender and Development Programme Paper No. 4. Geneva: United Nations Research Institute for Social Development.

Bukodi, Erzsébet, and Péter Róbert. 2007. Occupational mobility in Europe. Dublin.

Cancian, Francesca M., and Stacey J. Oliker. 2000. Caring and Gender (Gender Lens). Walnut Creek: AltaMira Press.

Cranford, Cynthia J., Leah F. Vosko, and Nancy Zukewich. 2003. The gender of precarious employment in Canada. Relations Industrielles/Industrial Relations 58 (3): 454-82.

Crenshaw, Kimberlé. 1991. Mapping the margins: Intersectionality, identity politics, and violence against women of color. Standford Law Review 43 (6): 1241-99.

Da Roit, B., and B. Weicht. 2013. Migrant care work and care, migration and employment regimes: A fuzzy-set analysis. Journal of European Social Policy 23 (5): 469-86.

Duffy, Mignon. 2005. Reproducing labor inequalities: Challenges for feminists conceptualizing care at the intersection of gender, race and class. Gender \& Society 19 (1): $66-82$.

- 2007. Doing the dirty work. Gender, race and reproductive labor in historical perspective. Gender \& Society 21 (3): 313-36.

Duffy, Mignon, Randy Albelda, and Clare Hammonds. 2013. Counting care work: The empirical and policy applications of care theory. Source: Social Problems 60 (2): $145-67$.

Ehrenreich, Barbara, and Arlie Hochschild. 2002. Global woman: Nannies, maids and sex workers in the new economy. New York, NY: Holt Paperbacks. 
Eichhorst, Werner, and Paul Marx, eds. 2015. Non-standard employment in post-industrial labour markets: An occupational perspective. Vol. 1. Cheltenham: Edward Elgar.

England, Paula. 2005. Emerging theories of care work. Annual Review of Sociology 31: 381-99.

England, Paula, Michelle Budig, and Nancy Folbre. 2002. Wages of virtue: The relative pay of care work. Social Problems 49 (4): 455-73.

England, Paula, and Nancy Folbre. 1999. The cost of caring. Annals of the American Academy of Political and Social Science 561 (1): 39-51.

Esping-Andersen, Gösta. 1990. The three worlds of welfare capitalism. Princeton: Princeton University Press.

European Commission. 2012. Commission staff working document on exploiting the employment potential of the personal and household services. SWD(2012)95 final.

Finotelli, Claudia, and Joaquín Arango. 2011. Regularisation of unauthorised immigrants in Italy and Spain: Determinants and effects. Documents d'Anàlisi Geogràfica 57 (3): 495-515.

Folbre, Nancy. 2006. Measuring care: Gender, empowerment, and the care economy. Journal of Human Development 7 (2): 183-99.

Gallotti, Maria. 2009. The gender dimension of domestic work in Western Europe. Geneva: International Labour Organization.

Glenn, E. N. 1992. From servitude to service work: Historical continuities in the racial division of paid reproductive labor. Signs 18 (1): 1-43.

Greenhaus, Jeffrey H., and Nicholas J. Beutell. 1985. Sources of conflict between work and family roles. Academy of Management Review 10 (1): 76.

Gurung, Shobha Hamal. 2009. Journal of Workplace Rights 14 (3): 375-96.

Hellgren, Zenia. 2015. Markets, regimes, and the role of stakeholders: Explaining precariousness of migrant domestic/care workers in different institutional frameworks. Social Politics: International Studies in Gender, State \& Society 22 (2): 220-41.

Hellgren, Zenia, and Inma Serrano. 2017. Transnationalism and financial crisis: The hampered migration projects of female domestic workers in Spain. Social Sciences 6 (1): 8.

Hobson, Barbara, and Luwam Bede. 2015. Precariousness and capabilities: Migrant care/domestic workers. Teorija in Praksa 52 (3): 327-49.

Hobson, Barbara, Zenia Hellgren, and Luwam Bede. 2015. How institutional contexts matter: Migration and domestic care services and the capabilities of migrants in Spain and Sweden. Vol. 46. Families and Societies. Working paper 46. http://www. familiesandsocieties.eu/wp-content/uploads/2017/03/WorkingPaper46.pdf.

ILO. 2013. Domestic workers across the world: Global and regional statistics and the extent of legal protection. Geneva: International Labour Office.

Jokela, Merita. 2017. The role of domestic employment policies in shaping precarious work. Social Policy \& Administration 51 (2): 286-307.

Jönson, Håkan, and Anders Giertz. 2013. Migrant care workers in Swedish elderly and disability care: Are they disadvantaged? Journal of Ethnic and Migration Studies 39 (5): 809-25.

Kalleberg, Arne L. 2000. Nonstandard employment relations: Part-time, temporary and contract work. Annual Review of Sociology 26 (2000): 341-65.

- 2009. Precarious work, insecure workers: Employment relations in transition. American Sociological Review 74: 1-22. 
2011. Good jobs, bad jobs: The rise of polarized and precarious employment systems in the United States, 1970s-2000s. New York, NY: Russell Sage Foundation.

Kalleberg, Arne L . 2012. Job quality and precarious work: Clarifications, controversies, and challenges. Work and Occupations 39 (4): 427-48.

Kvist, Elin. 2012. Changing social organizations of care: A comparison of European policy reforms encouraging paid domestic work. European Journal of Ageing 9: 111-17.

Leitner, Sigrid. 2003. Varieties of familialism: The caring function of the family in comparative perspective. European Societies 5 (4): 353-75.

León, Margarita 2010. Migration and care work in Spain: The domestic sector revisited. Social Policy and Society 9 (3): 409-18.

Leschke, Janine. 2015. Non-standard employment of women in service sector occupations: A comparison of European countries. In Non-standard employment in post-industrial labour markets: An occupational perspective, edited by Werner Eichhorst and Paul Marx, 324-52. Cheltenham: Edward Elgar.

Lightman, Naomi. 2017. Discounted labour? Disaggregating care work in comparative perspective. International Labour Review 156(2): 243-67.

Lister, Ruth, Fiona Williams, Anneli Anttonen, Jet Bussemaker, Ute Gerhard, Jacqueline Heinen, Stina Johansson, et al., eds. 2007. Gendering citizenship in Western Europe: New challenges for citizenship research in a cross-national context. Bristol: The Policy Press.

Lutz, Helma. 2009. Migrantinnen in der Pflege in Deutschen Privathaushalten. In Illegale Beschäftigung in Europa. Die Situation in Privathaushalten älterer Personen, edited by C. Larsen, A. Joost, and S. Heid. München/Mering: Rainer Hampp.

- 2011. The New Maids: Transnational women and the care economy. London: Zed.

Marchetti, Sabrina. 2013. Dreaming circularity? Eastern European women and job sharing in paid home care. Journal of Immigrant \& Refugee Studies 11 (4): 347-63.

Meagher, Gabrielle, Marta Szebehely, and Jane Mears. 2016. How institutions matter for job characteristics, quality and experiences: A comparison of home care work for older people in Australia and Sweden. Work, Employment \& Society 30 (5): 731-49.

Michel, S., and I. Peng. 2012. All in the family? Migrants, nationhood, and care regimes in Asia and North America. Journal of European Social Policy 22 (4): 406-18.

Milkman, R., E. Reese, and B. Roth. 1998. The macrosociology of paid domestic labor. Work and Occupations 25: 483-510.

Minijobzentrale. 2015. II. Quartalsbericht 2015: Aktuelle Entwicklungen im Bereich der geringfügigen Beschäftigung. Essen.

Mohanty, Chandra Talpade. 2003. Feminism without borders: Decolonizing theory, practicing solidarity. Contributions to Indian Sociology 19: 312.

Morel, Nathalie. 2007. From subsidiarity to 'free choice': Child- and elder-care policy reforms in France, Belgium, Germany and the Netherlands. Social Policy \& Administration 41 (6): 618-37.

2015. Servants for the knowledge-based economy? The political economy of domestic services in Europe. Social Politics: International Studies in Gender, State \& Society 22 (2): 170-92.

Morgan, Kimberly J. 2005. The "production" of child care: How labor markets shape social policy and vice versa. Social Politics. 
OECD. 2015a. OECD economic surveys Luxembourg. Paris: OECD Publishing.

OECD. 2015b. OECD employment outlook 2015. Paris: OECD Publishing.

Parreñas Salazar, Rhacel. 2000. Migrant Filipina domestic workers and the international division of reproductive labour. Gender \& Society 14 (4): 560-80.

- 2012. The reproductive labour of migrant workers. Global Networks 12: 269-75.

- 2014. Migrant domestic workers as 'one of the family'. In Migration and care labour: Theory, policy and politics, edited by Bridget Anderson and Isabel Shutes, 49-64. London: Palgrave Macmillan.

Pratt, Geraldine. 2005. From migrant women to immigrant: Domestic workers settle in Vancouver, Canada. In A companion to feminist geography, edited by Lise Nelson and Joni Seager, 123-37. Malden, MA: Blackwell.

Prosser, Thomas. 2016. Dualization or liberalization? Investigating precarious work in eight European countries. Work, Employment \& Society 30 (6): 949-65.

Pyöriä, P, and S Ojala. 2016. Precarious work and intrinsic job quality: Evidence from Finland, 1984-2013. Economic and Labour Relations Review 27 (3): 349-67.

Roberts, Dorothy. 1997. Spiritual and menial housework. Yale Journal of Law and Feminism 9: 51-80.

Rodgers, Gerry, and Janine Rodgers, eds. 1989. Precarious jobs in labour market regulation: The growth of atypical employment in Western Europe. Geneva: International Labour Organization.

Rueda, David. 2005. Insider-outsider politics in industrialized democracies: The challenge to social democratic parties. American Political Science Review 99 (1): 61-74.

- 2007. Social democracy inside out. Oxford: Oxford University Press.

- 2014. Dualization, crisis and the welfare state. Socio-Economic Review 12: 381-407.

Shire, Karen. 2015. Family supports and insecure work: The politics of household service employment in conservative welfare regimes. Social Politics: International Studies in Gender, State \& Society 22 (2): 193-219.

Shutes, Isabel, and Carlos Chiatti. 2012. Migrant labour and the marketisation of care for older people: The employment of migrant care workers by families and service providers. Journal of European Social Policy 22 (4): 392-405.

Shutes, Isabel, and Kieran Walsh. 2012. Negotiating user preferences, discrimination, and demand for migrant labour in long-term care. Social Politics: International Studies in Gender, State and Society 19 (1): 78-104.

Simonazzi, Annamaria. 2008. Care regimes and national employment models. Cambridge Journal of Economics 33 (2): 211-32.

- 2012. Time, cash and services: Reforms for a future sustainable long-term care. Futures 44 (7): 687-95.

Standing, Guy. 1989. Global feminization through flexible labor. World Development 17 (7): 1077-95.

- 2011. The precariat: The new dangerous class. London: Bloomsbury Academic.

Steinberg, Ronnie J. 1990. Social construction of skill: Gender, power, and comparable worth. Work and Occupations 17: 449-82.

Suleman, Fátima. 2015. The employment relationship in an (almost) structureless labour market: The case of domestic work. Cambridge Journal of Economics 39 (3): 733-50. 
Theobald, Hildegard. 2010. Conditions and challenges of Germany's long-term care insurance: Care policies and inequalities based on gender, socio-economic class and ethnicity. Journal of Asian Women's Studies 18: 1-12.

Tomei, Manuela. 2011. Decent work for domestic workers: Reflections on recent approaches to tackle informality. Canadian Journal of Women and the Law/Revue Femmes et Droit 23 (1): 185-211.

Triandafyllidou, Anna, and Sabrina Marchetti. 2013. Migrant domestic and care workers in Europe: New patterns of circulation? Journal of Immigrant \& Refugee Studies 11 (4): 339-46.

Ungerson, Clare. 1997. Social politics and the commodification of care. Social Politics: International Studies in Gender, State \& Society 4: 363-81.

van Hooren, Franca Janna. 2010. When families need immigrants: The exceptional position of migrant domestic workers and care assistants in Italian immigration policy. Bulletin of Italian Politics 2 (2): 21-38.

van Hooren, Franca Janna. 2011. Caring migrants in European welfare regimes: The policies and practice of migrant labour filling the gaps in social care. European University Institute.

van Walsum, Sarah. 2011. Regulating migrant domestic work in the Netherlands: Opportunities and pitfalls. Canadian Journal of Women and the Law 23 (1): 141-65.

Vosko, Leah F. 2000. Temporary work: The gendered rise of a precarious employment relationship. Toronto: University of Toronto Press.

- 2006. Precarious employment: Understanding labour market insecurity in Canada. Montreal: McGill-Queen's University Press.

Vosko, Leah F., Martha MacDonald, and Iain Campbell, eds. 2009. Gender and the contours of precarious employment. New York, NY: Routledge.

Weeden, Kim A. 2002. Why do some occupations pay more than others? Social closure and earnings inequality in the United States. American Journal of Sociology 108 (1): 55-101.

Williams, F. 2012. Converging variations in migrant care work in Europe. Journal of European Social Policy 22 (4): 363-76.

Williams, Fiona, and Anna Gavanas. 2008. The intersection of childcare regimes and migration regimes: A three-country study. In Migration and domestic work: A European perspective on a global theme, edited by Helma Lutz, 13-28. Surrey: Ashgate.

Young, Marisa C. 2010. Gender differences in precarious work settings. Industrial Relations 65 (1): 74-97. 